\title{
Pengaruh Konsentrasi Ekstrak Kulit Buah Naga Merah terhadap Pertum- buhan Streptococcus mutans pada Sediaan Obat Kumur (Uji Invitro)
}

\author{
Bitha Ariyani, ${ }^{1}$ Desy Armalina, ${ }^{2}$ Diah A. Purbaningrum ${ }^{3}$
}

\author{
${ }^{1}$ Program Studi Pendidikan Kedokteran Gigi Fakultas Kedokteran Universitas Diponegoro, \\ Semarang, Indonesia \\ ${ }^{2}$ Departemen Histologi Fakultas Kedokteran Universitas Diponegoro, Semarang, Indonesia \\ ${ }^{3}$ Departemen Kedokteran Gigi Fakultas Kedokteran Universitas Diponegoro, Semarang, \\ Indonesia \\ Email: bitha175ariyani@gmail.com \\ Disubmisi: 4 Juli 2021; direvisi: 16 Juli 2021; diterima: 17 Juli 2021
}

\begin{abstract}
Caries could be minimized by reducing plaque accumulation with an antiseptic mouthwash. However, chlorhexidine $0,2 \%$, the gold standard mouthwash, is known to have side effects. This has led to the innovation of an alternative herbal-based mouthwash that has antibacterial properties; one of the possible natural material is red dragon fruit peels. This study was aimed to prove the effect of red dragon fruit peel extract as mouthwash prepared in several concentrations to inhibit the growth of Streptococcus mutans. This was a quasi-experimental study with the post test control group design. There were six sample groups, namely mouthwash with extract concentration of $6.25 \%, 12.5 \%, 25 \%$, and $50 \%$, negative control (aquadest), and positive control (chlorhexidine $0.2 \%$ ). The antibacterial assessment was done by using the well diffusion method calculating the inhibition zone formed around the wellbore. Data were analyzed by using the Kruskal Wallis test and the Mann Whitney Post Hoc test. The results showed that the average inhibition zones formed by extract mouthwash of $6.25 \%$, $12.5 \%, 25 \%, 50 \%$ were $3.18 \mathrm{~mm}, 5.13 \mathrm{~mm}, 7.30 \mathrm{~mm}$, and $11.01 \mathrm{~mm}$ respectively, and by positive control was $14.65 \mathrm{~mm}$. There were significant differences between each treatment group. All concentrations of red dragon fruit peel extract in mouthwash could inhibit effectively the growth of Streptococcus mutans although not as effective as the positive control. In conclusion, red dragon fruit peel extract mouthwash could inihibit the growth of Streptococcus mutans.
\end{abstract}

Keywords: mouthwash; red dragon fruit peel; Streptococcus mutans; antibacterial effect

\begin{abstract}
Abstrak: Karies dapat diminimalisasi dengan mengurangi akumulasi plak menggunakan obat kumur antiseptik. Obat kumur chlorhexidine 0,2\% merupakan obat kumur baku emas namun memiliki efek samping. Hal tersebut memunculkan inovasi untuk mencari alternatif obat kumur berbahan dasar herbal yang memiliki sifat antibakteri; salah satunya ialah kulit buah naga merah. Penelitian ini bertujuan membuktikan pengaruh ekstrak kulit buah naga merah dalam obat kumur dengan beberapa konsentrasi untuk menghambat pertumbuhan Streptococcus mutans penyebab karies. Jenis penelitian ialah quasi experimental dengan desain post test only group control design. Terdapat enam kelompok sampel yaitu obat kumur konsentrasi ekstrak 6,25\%, 12,5\%, 25\%, 50\%, kontrol (-) akuades, dan kontrol (+) chlorhexidine $0,2 \%$. Uji antibakteri menggunakan metode difusi sumuran dengan menghitung zona hambat yang terbentuk di sekitar lubang sumuran. Uji statistik menggunakan Kruskal Wallis dan uji post hoc Mann Whitney. Hasil penelitian mendapatkan rerata zona hambat yang terbentuk dari obat kumur konsentrasi ekstrak 6,25\%, 12,5\%, 25\%, 50\% ialah 3,18 mm, 5,13 mm, 7,30 $\mathrm{mm}, 11,01 \mathrm{~mm}$, dan kelompok kontrol(+) ialah 14,56 $\mathrm{mm}$. Perbedaan bermakna terdapat pada setiap kelompok perlakuan. Setiap konsentrasi ekstrak kulit buah naga merah dalam obat kumur berpengaruh menghambat pertumbuhan bakteri Streptococcus mutans, namun belum sebaik kontrol (+). Simpulan penelitian ini ialah ekstrak kulit buah naga merah dalam obat kumur berpengaruh menghambat pertumbuhan bakteri Streptococcus mutans.
\end{abstract}

Kata kunci: obat kumur; kulit buah naga merah; Streptococcus mutans; efek antibakteri 


\section{PENDAHULUAN}

Hasil Riset Kesehatan Dasar (RISKESDAS) pada tahun 2018 menyebutkan bahwa prevalensi penyakit karies di Indonesia mencapai 88,8\%. ${ }^{1}$ Karies merupakan penyakit kronis umum yang melibatkan interaksi antara struktur keras permukaan gigi, biofilm yang terbentuk pada permukaan gigi, gusi, saliva, serta genetik. $^{2}$ Faktor-faktor penyebab terjadinya karies terdiri dari faktor yang berasal dari luar individu dan faktor yang berasal dari dalam individu. Faktor yang berasal dari luar individu meliputi ras, usia, makanan, dan jenis kelamin sedangkan faktor-faktor yang berasal dari dalam individu terdiri dari pejamu, waktu, substrat, dan mikroorganisme. ${ }^{3}$

Proses terjadinya karies ditandai dengan munculnya bercak putih pada permukaan gigi. ${ }^{4}$ Mekanisme terjadinya karies terdiri dari dua periode yaitu periode demineralisasi dan periode reminarelalisasi. Proses-proses tersebut terjadi secara bergantian dalam waktu yang singkat. ${ }^{2}$ Ketika proses remineralisasi lebih lambat dibandingkan proses demineralisasi, maka yang akan terjadi $\mathrm{pH}$ normal dalam rongga mulut $(6,2-7,6)$ akan turun menjadi 5,5.5,6 Penurunan $\mathrm{pH}$ dalam rongga mulut disebabkan oleh adanya produksi asam organik yang dihasilkan oleh bakteri Streptococcus mutans. $^{2}$

Bakteri Streptococcus mutans merupakan bakteri yang paling dominan dan menjadi salah satu bakteri yang menginsiasi terjadinya karies gigi dengan memroduksi asam organik yang tinggi. ${ }^{7,8}$ Peningkatan produksi asam organik dalam rongga mulut menyebabkan terlarutnya lapisan mineral pada permukaan enamel dan apabila proses tersebut berlangsung terus menerus maka menyebabkan terjadinya karies gigi. ${ }^{2}$ Bakteri Streptococcus mutans merupakan bakteri yang paling dominan dan menjadi salah satu bakteri yang menginsiasi terjadinya karies gigi dengan memroduksi asam organik yang tinggi. ${ }^{7,8}$

Upaya meminimalisasi terjadinya karies gigi yang dapat dilakukan yaitu dengan mengurangi akumulasi plak menggunakan obat kumur antiseptik. ${ }^{9}$ Obat kumur chlorhexidine $0,2 \%$ merupakan obat kumur baku emas yang bersifat antimikroba berspektrum luas dan efektif dalam melawan berbagai jenis bakteri Gram positif, Gram negatif, dan golongan jamur, serta efektif mengurangi jumlah bakteri Streptococcus mutans penyebab karies. ${ }^{10-15}$

Efek samping penggunaan obat kumur chlorhexidine $0,2 \%$ dapat menimbulkan pewarnaan pada gigi, bahan restorasi pada gigi, serta dorsum lidah. Efek samping lain yang ditimbulkan ialah menurunkan kepekaan rasa pada lidah, serta meningkatkan terjadinya pembentukan karang gigi. ${ }^{16,17}$ Berdasarkan efek samping penggunaan obat kumur chlorhexidine $0,2 \%$, maka perlu dilakukan inovasi baru, berupa pencarian alternatif lain berupa obat kumur berbahan dasar tumbuhan yang memiliki sifat antibakteri.

Buah naga merah (Hylocereus polyrhizus) merupakan jenis buah naga yang banyak ditemukan di Indonesia. ${ }^{18}$ Bagian dari buah naga yang dimanfaatkan dalam penelitian ini ialah kulit buahnya. Kulit buah naga merah dipilih karena optimalisasi pemanfaatan kulit buah naga merah cenderung rendah, sehingga kulit buah naga merah hanya menjadi limbah organik dari setiap penggunaannya. ${ }^{19}$

Buah naga merah (Hylocereus polyrhizus) diketahui memiliki sifat antimikroba yang baik terhadap kelompok bakteri Gram positif dan bakteri Gram negatif. ${ }^{20}$ Berdasarkan hasil pemeriksaan skrining fitokimia pada ekstrak kulit buah naga merah (Hylocereus polyrhizus) menunjukkan hasil positif terhadap adanya senyawa metabolit sekuder seperti tannin, saponin, alkaloid, phenol hidroquinone, flavonoid, triterpenoid, dan steroid. ${ }^{21-22}$

Berdasarkan senyawa yang terdapat dalam kandungan ekstrak kulit buah naga merah (Hylocereus polyrhizus) maka penulis tertarik untuk mengetahui pengaruh konsentrasi ekstrak kulit buah naga merah (Hylocereus polyrhizus) dalam bentuk sediaan obat kumur yang menghambat pertumbuhan bakteri Streptococcus mutans penyebab karies. 


\section{METODE PENELITIAN}

Penelitian ini dilaksanakan di Laboratorium Mikrobiologi Fakultas Kedokteran Universitas Diponegoro. Jenis penelitian ialah suatu quasi experimental dengan post test only group control design. Penelitian ini menggunakan metode difusi sumuran agar, dimana permukaan plat agar diinokulasikan dengan menyebarkan mikroorganisme uji pada seluruh permukaan plat agar kemudian media blood agar dilubangi mengunakan sterile cork borer dengan diameter 6-8 mm. Ketika lubang sumuran telah terbentuk larutan yang diuji kemampuan antibakterinya dimasukkan kedalam lubang sumuran sebanyak $20-100 \mathrm{ml}^{23}$

Alat yang diperlukan dalam penelitian ini yaitu: pisau stainless steel, talenan, timbangan analitik, gelas ukur, becker glass, erlenmeyer, mikropipet, batang pengaduk, rotary evaporator, lemari pendingin, plastik pembungkus simplisia kulit buah naga, botol kaca coklat, ayakan, blender, autoclave, kertas saring, aluminium foil, timbangan analitik, sonikator, labu takar $100 \mathrm{ml}$, inkubator, ose steril disposable, kapas alkohol, cork borer, cawan Petri disposable, korek api, cairan spiritus, pipet, jangka sorong ketelitian $0,01 \mathrm{~mm}$, tabung reaksi, rak tabung reaksi, $\mathrm{pH}$ meter, vortex mixer, dan laminar flow.

Bahan-bahan yang digunakan dalam penelitian ini meliputi: kulit buah naga merah, pelarut etanol $96 \%$, gliserin $5 \%$, sodium saccharine $0,001 \%$, natrium benzoat $0,1 \%$, air suling $100 \mathrm{ml}$, suspensi bakteri Streptococcus mutans yang diperoleh dari Laboratorium Mikrobiologi Fakultas Kedokteran Universitas Diponegoro, obat kumur chlorhexidine $0,2 \%$, larutan akuades steril, larutan 0,5 Mc Farland, dan media blood agar.

Tahap pertama yaitu mengumpulkan alat dan bahan. Buah naga merah didapatkan langsung dari hasil panen salah satu perkebunan buah naga merah di Kota Banyuwangi, Jawa Timur. Determinasi tumbuhan yang dilakukan di Laboratorium Ekologi dan Biosistematik Departemen Biologi Fakultas Sains dan Matematika Universitas Diponegoro. Tahap berikutnya membuat ekstrak kulit buah naga merah.
Buah naga yang telah tekumpul dicuci di bawah air mengalir dan ditiriskan. Kulit buah naga dipisahkan dengan daging buahnya. Kulit buah naga yang telah terkumpul dikeringkan dengan cara diangin-anginkan hingga kering kemudian dihaluskan menggunakan blender.

Simpilisia kulit buah naga yang telah diblender direndam dalam wadah tertutup dengan menggunakan pelarut etanol $96 \%$ hingga menutupi $\pm 1 \mathrm{~cm}$ di atas simplisia. Proses ekstraksi menggunakan metode maserasi selama $3 \times 24$ jam. Setiap 24 jam larutan etanol diganti dan disaring menggunakan kertas saring. Ketika proses perendaman telah selesai dilakukan proses penguapan pada suhu $50^{\circ} \mathrm{C}$ selama 2 jam menggunakan rotary evaporator hingga menghasilkan ekstrak kental dan pekat yang kemudian disimpan dalam wadah tertutup dan diletakkan di dalam lemari pendingin.

Proses pembuatan obat kumur dilakukan dengan menimbang bahan-bahan meliputi ekstrak kulit buah naga merah (sebanyak $50 \mathrm{gr}, 25 \mathrm{gr}, 12,5 \mathrm{gr}, 6,25 \mathrm{gr}$ ), sodium saccharin $0,001 \mathrm{gr}$, sodium benzoat $0,1 \mathrm{gr}$, gliserin $5 \mathrm{ml}$, dan air suling dicukupkan hingga $100 \mathrm{ml}$. Bahan-bahan tersebut dimasukkan ke dalam labu takar $100 \mathrm{ml}$ dan dilakukan homogenisasi menggunakan alat sonikator. Larutan obat kumur disimpan dalam botol coklat dan diberi label sesuai dengan konsentrasi ekstrak kulit buah naga merah.

Uji antibakteri obat kumur ekstrak kulit buah naga merah menggunakan metode sumuran. Langkah kerja pertama ialah sterilisasi alat menggunakan autoklaf. Prosedur kedua membuat media blood agar dengan bubuk blood agar sebanyak 40 gr dilarutkan dengan larutan akuades sebanyak 1000 $\mathrm{mL}$ pada tabung Erlenmeyer dan dihomogenisasi, kemudian dilakukan sterilisasi menggunakan autoklaf. Larutan tersebut dikeluarkan dari autoklaf dan ditunggu hingga suhu mencapai $50^{\circ} \mathrm{C}$, kemudian ditambahkan darah serta dilakukan pengadukan hingga homogen

Larutan dituang pada cawan Petri dan ditunggu hingga mengeras dan larutan men- 
jadi dingin. Permukaan media blood agar dilubangi menggunakan cork borer steril. Prosedur berikutnya ialah membuat suspensi bakteri Streptococcus mutans. Suspensi dibuat dengan mengambil biakan bakteri Streptococcus mutans dengan ose steril sebanyak 1-2 ose, kemudian dimasukkan ke dalam tabung reaksi yang telah terisi $2 \mathrm{ml}$ larutan $\mathrm{NaCl}$ 0,9\% hingga kekeruhan sesuai dengan larutan standar $0,5 \mathrm{McF}$ arland yaitu $1,5 \times 10^{8} \mathrm{CFU} / \mathrm{ml}$. Proses homogenisasi dilakukan dengan menggunakan vortex mixer.

Proses uji antibakteri dilakukan dengan memasukkan obat kumur ekstrak kulit buah naga ke dalam setiap lubang sumuran sebanyak $100 \mu$ l. Setiap lubang sumuran hanya terisi satu jenis obat kumur ekstrak kulit buah naga dengan konsentrasi tertentu. Inkubasi dilakukan selama 24 jam pada suhu $37^{\circ} \mathrm{C}$. Zona hambat yang telah terbentuk di sekitar lubang sumuran diamati dan diukur menggunakan jangka sorong dengan ketelitian 0,01 $\mathrm{mm}$. Pengukuran zona dilakukan dengan mengukur jarak garis: $\mathrm{AD}$, ad, BE, be, CF, dan cf (Gambar 1). Garis AD merupakan suatu garis yang dibuat dengan melalui titik pusat lingkaran. Garis BE merupakan garis tegak, yang dibuat tegak lurus terhadap garis AD. Garis $\mathrm{CF}$ merupakan garis diagonal yang membagi sudut garis $\mathrm{AD}$ dan garis $\mathrm{BE}$ sebesar $45^{\circ}$. Garis ad, be, dan garis cf merupakan garis yang memotong lingkaran bagian dalam.

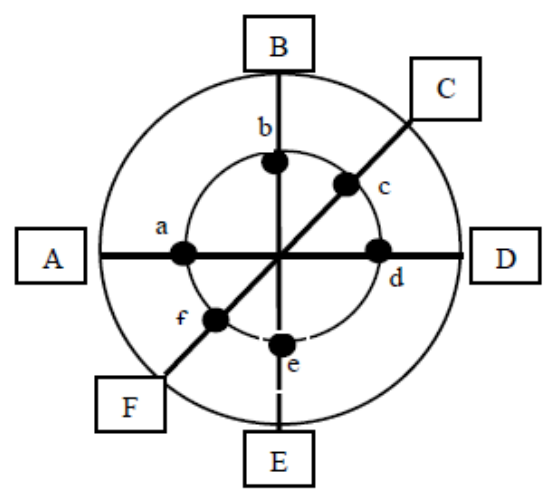

Gambar 1. Zona hambat. Sumber: Levinson dan Jawetz, 1994, dalam Andhika et al, 2007. ${ }^{24}$
Pembacaan setiap zona dilakukan sesuai dengan Gambar 1. Terdapat tiga pembacaan zona hambat, yaitu: 1) Zona pembacaan I mengukur panjang garis $\mathrm{AD}$ dikurangi panjang garis ad; 2) Zona pembacaan II mengukur panjang garis $\mathrm{BE}$ dikurangi panjang garis be; dan 3) Zona pembacaan III mengukur panjang garis FC dikurangi panjang garis fc. Tahap berikutnya ialah menghitung rerata dari setiap zona pembacaan dengan cara menjumlahkan pembacaan zona I, zona II, dan zona III kemudian dibagi tiga, sesuai dengan rumus yang tercantum (Levinson dan Jawetz, 1994): ${ }^{24}$

$$
Z H=\frac{(A D-a d)+(B E-b e)+(C D-c d)}{3}
$$

\section{HASIL PENELITIAN}

Tabel 1 memperlihatkan bahwa nilai rerata zona hambat yang terbentuk dari obat kumur dengan konsentrasi ekstrak kulit buah naga merah $6,25 \%, 12,5 \%, 25 \%$, dan $50 \%$ ialah $3,18 \mathrm{~mm}, 5,13 \mathrm{~mm}, 7,30 \mathrm{~mm}$, dan $11,01 \mathrm{~mm}$. Hasil rerata zona hambat yang terbentuk dari kontrol (+) yang menggunakan obat kumur chlorhexidine 0,2\% menghasilkan zona hambat yaitu 14,65 mm. Uji normalitas pada penelitian ini menggunakan uji Saphiro-Wilk karena jumlah sampel kurang dari 50. Hasil uji statistik menunjukkan bahwa data penelitian terdistribusi normal $(\mathrm{p}>0,05)$ sedangkan hasil uji homogenitas menunjukkan nilai $\mathrm{p}=0,006(\mathrm{p}<0,05)$ yang berarti bahwa data penelitian tidak homogen. Oleh karena data terdistribusi normal dan tidak homogen maka dilanjutkan dengan uji nonparametrik Kruskall-Wallis yang mendapatkan nilai $\mathrm{p}=0,000(\mathrm{p}<0,05)$ yang berarti bahwa terdapat pengaruh konsentrasi ekstrak kulit buah naga merah terhadap pertumbuhan Streptococcus mutans dalam sediaan obat kumur. Tahap berikutnya dilakukan uji post hoc Mann-Whitney untuk melihat perbedaan antara setiap kelompok perlakuan.

Tabel 2 memperlihatkan bahwa terdapat perbedaan bermakna pada setiap kelom- 
pok perlakuan $(\mathrm{p}<0,05)$. Hasil uji post hoc Mann Whitney mendapatkan adanya perbedaan bermakna pada kelompok kontrol negatif dengan kontrol positif dan obat kumur konsentrasi ekstrak $(6,25 \%, 12,5 \%$, $25 \%$, dan $50 \%$ ) dengan nilai $\mathrm{p}=0,014$ yang berarti terdapat perbedaan bermakna antara setiap kelompok perlakuan. Kelompok kontrol (+) dengan kelompok obat kumur konsentrasi ekstrak $(6,25 \%, 12,5 \%, 25 \%$, $50 \%$ ) mendapatkan nilai $\mathrm{p}=0,021$ yang berarti terdapat perbedaan bermakna antara setiap kelompok perlakuan. Kelompok obat kumur konsentrasi ekstrak 6,25\% dengan obat kumur konsentrasi ekstrak 12,5\%, $25 \%$, dan $50 \%$ mendapatkan nilai $\mathrm{p}=0,021$ yang berarti terdapat perbedaan bermakna antara setiap kelompok perlakuan. Kelompok obat kumur konsentrasi ekstrak 12,5\% dengan obat kumur konsentrasi ekstrak $25 \%$ dan $50 \%$ mendapatkan nilai $\mathrm{p}=0,021$ yang berarti terdapat perbedaan bermakna antara setiap kelompok perlakuan. Kelompok obat kumur konsentrasi ekstrak $25 \%$ dengan obat kumur konsentrasi ekstrak
$50 \%$ mendapatkan nilai $\mathrm{p}=0,021$ yang berarti terdapat perbedaan bermakna antara setiap kelompok perlakuan.

\section{BAHASAN}

Uji antibakteri menunjukkan bahwa sediaan obat kumur ekstrak kulit buah naga merah dengan konsentrasi $6,25 \%, 12,5 \%$, $25 \%$, dan $50 \%$ mampu menghambat pertumbuhan Streptococcus mutans. Pengaruh tersebut disebabkan oleh adanya senyawa metabolit sekunder yang terkandung dalam ekstrak kulit buah naga merah. Manihuruk et $\mathrm{a}^{25}$ menyatakan bahwa ekstrak kulit buah naga merah mengandung senyawa flavornoid, phenol hidroquinone, steroid, triterpenoid, tannin, dan saponin. Menurut Suhartati dan Dodi ${ }^{21}$ senyawa lain yang terkandung dalam ekstrak kulit buah naga merah yaitu senyawa alkaloid, tannin, dan saponin.

Mekanisme umum senyawa metabolit sekunder dalam menghambat pertumbuhan Streptococcus mutans yaitu dengan cara menghambat sintesis peptidoglikan. ${ }^{26-28}$

Tabel 1. Nilai rerata, standar deviasi, median, minimum, maksimum, dan uji normalitas

\begin{tabular}{cccc}
\hline Kelompok & Mean \pm SD & Median $($ min-maks) & p \\
\hline Kontrol - & $0,00 \pm 0,00$ & $0(0-0)$ & - \\
Kontrol + & $14,65 \pm 0,77$ & $14,62(13,96-15,41)$ & $0,103^{*}$ \\
OKKE 6,25\% & $3,18 \pm 0,39$ & $3,21(2,75-3,56)$ & $0,370^{*}$ \\
OKKE 12,5\% & $5,13 \pm 0,27$ & $5,03(4,94-5,53)$ & $0,083^{*}$ \\
OKKE 25\% & $7,30 \pm 0,47$ & $7,27(6,82-7,81)$ & $0,442^{*}$ \\
OKKE 50\% & $11,01 \pm 1,25$ & $10,62(10,01-12,82)$ & $0,271^{*}$ \\
\hline
\end{tabular}

Keterangan : *Normal (p>0.05); Uji Saphiro Wilk; OKKE: Obat kumur konsentrasi ekstrak

Tabel 2. Uji post hoc Mann Whitney

\begin{tabular}{ccccccc}
\hline & Kontrol & Kontrol & $\begin{array}{c}\text { Nilai p } \\
\text { OKKE } \\
(-)\end{array}$ & $\begin{array}{c}\text { OKKE } \\
\mathbf{6 , 2 5 \%}\end{array}$ & $\begin{array}{c}\text { ECM } \\
\mathbf{1 2 5 \%}\end{array}$ & $\begin{array}{c}\text { ECM } \\
\mathbf{2 5 \%}\end{array}$ \\
\hline Kontrol (-) & - & 0,014 & 0,014 & 0,014 & 0,014 & 0,014 \\
Kontrol (+) & 0,014 & - & 0,021 & 0,021 & 0,021 & 0,021 \\
OKKE 6,25\% & 0,014 & 0,021 & - & 0,021 & 0,021 & 0,021 \\
OKKE 12,5\% & 0,014 & 0,021 & 0,021 & - & 0,021 & 0,021 \\
OKKE 25\% & 0,014 & 0,021 & 0,021 & 0,021 & - & 0,021 \\
OKKE 50\% & 0,014 & 0,021 & 0,021 & 0,021 & 0,021 & - \\
\hline
\end{tabular}

Keterangan: *Bermakna $(\mathrm{p}<0,05)$; OKKE: Obat kumur konsentrasi ekstrak 
Mekanisme senyawa phenol hydroquinone dalam menghambat pertumbuhan Streptococcus mutans ialah dengan merusak ikatan peptidoglikan dinding bakteri sehingga memengaruhi permeabilitas dinding sel dan membran sitoplasma bakteri. ${ }^{29}$ Permeablitias dinding sel yang terganggu menimbulkan ketidakseimbangan makromolekul di dalam sel dan menyebabkan terjadinya lisis hingga kematian sel bakteri. $^{30,31}$

Senyawa flavonoid merupakan senyawa paling besar dan terkuat yang terkandung dalam ekstrak kulit buah naga merah dibandingkan senyawa lainnya. ${ }^{32,33}$ Mekanisme flavonoid dalam menghambat pertumbuhan Streptococcus mutans ialah dengan cara menganggu aktivitas enzim glukotransferase (GTF). Enzim GTF yang terganggu mengakibatkan protein bakteri menjadi nonaktif dan proses demineralisasi gigi menjadi terhambat. ${ }^{34}$ Interaksi yang ditimbulkan oleh protein bakteri dengan senyawa flavonoid membentuk koagulasi protein pada dinding bakteri dan meningkatkan tekanan osmotik di dalam sel bakteri yang mencapai 5-20 atm. ${ }^{35,36}$ Peningkatan tekanan osmotik ini mampu memicu terjadinya kerusakan pada dinding sel bakteri hingga menyebabkan lisis. ${ }^{34}$

Obat kumur ekstrak kulit buah naga merah konsentrasi 50\% memiliki kemampuan menghambat pertumbuhan Streptococcus mutans yang lebih efektif dan menghasilkan zona hambat yang lebih luas daripada obat kumur dengan konsentrasi ekstrak 25\%, 12,5\%, dan 6,25\%. Kadar hambat minimum dihasilkan oleh obat kumur konsentrasi ekstrak 6,25\%, yaitu pada konsentrasi terkecil tersebut masih dapat menghambat pertumbuhan Streptococcus mutans.

Penelitian oleh Setiani ${ }^{37}$ mengenai efek antibakteri ekstrak kulit buah naga merah terhadap bakteri Pseudomonas sp menunjukkan bahwa ekstrak kulit buah naga merah memiliki kemampuan untuk menghambat pertumbuhan bakteri Gram negatif (Pseudomonas sp) pada konsentrasi minimum $15 \%$ dengan zona hambat sebesar 10 $\mathrm{mm}$ dan pada konsentrasi tertinggi $95 \%$ menghasilkan zona hambat $16 \mathrm{~mm}$. Sartika et $\mathrm{al}^{38}$ meneliti sifat antibakteri ekstrak kulit buah naga merah dalam menghambat pertumbuhan bakteri Escherichia coli dan melaporkan bahwa ekstrak kulit buah naga merah pada konsentrasi minimum 10\% dapat menghasilkan zona hambat 3,58 $\mathrm{mm}$ dan pada konsnetrasi tertinggi $100 \%$ dapat menghasilkan zona hambat sebesar 9,30 $\mathrm{mm}$. Penelitian yang dilakukan oleh Faridah et al $^{39}$ mengenai efek ekstrak kulit buah naga merah terhadap bakteri Escherichia coli dan bakteri Staphylococcus aureus menunjukkan bahwa bakteri Gram positif memiliki tingkat respon sensitivitas yang lebih baik terhadap adanya senyawa antibakteri dibandingkan tingkat respon sensitivitas yang dihasilkan oleh bakteri Gram negatif. Respon sensitivitas tersebut berhubungan dengan adanya perbedaan struktur dinding sel bakteri Gram negatif dan positif. ${ }^{39}$ Bakteri Gram positif memiliki susunan dinding sel yang lebih sederhana dibandingkan bakteri Gram negatif yaitu susunan dinding sel pada bakteri Gram posistif mengandung sedikit lipid, banyak mengandung peptidoglikan, dan tidak memiliki membran luar. ${ }^{40,41}$

Penelitian ini menggunakan Streptococcus mutans yang merupakan bakteri Gram positif dengan dinding sel yang tersusun atas $40 \%-80 \%$ peptidoglikan hingga mencapai 40 lapisan, bersifat polar, dan lebih mudah mengalami denaturasi yang disebabkan oleh susunan dinding selnya didominasi oleh peptidoglikan. ${ }^{28,42,43}$

Uji antibakteri pada penelitian ini menunjukkan bahwa obat kumur ekstrak kulit buah naga merah dengan konsentrasi $50 \%$ menghasilkan zona hambat yang paling luas di bandingkan dengan obat kumur ekstrak kulit buah naga merah dengan konsentrasi $25 \%, 12,5 \%$, dan 6,25\%. Berdasarkan hasil tersebut dapat disimpulkan bahwa obat kumur dengan konsentrasi ekstrak kulit buah naga merah yang semakin tinggi mampu menghasilkan zona hambat yang semakin luas. ${ }^{44}$ Hasil penelitian ini sejalan dengan penelitian yang dilakukan oleh Agung et $\mathrm{al}^{45}$ yang menunjukkan bahwa seiring meningkatnya kon- 
sentrasi ekstrak etanol kulit buah naga merah dapat meningkatkan kemampuan menghambat pertumbuhan bakteri. Konsentrasi ektrak yang tinggi mengandung senyawa bioaktif yang semakin banyak sehingga hal tersebut memengaruhi luas zona hambat. ${ }^{46}$ Kategori kekuatan aktivitas daya hambat menurut David dan Stout (1971) dibagi menjadi empat kategori, yaitu sangat kuat $(\geq 20 \mathrm{~mm})$, kuat $(10-20 \mathrm{~mm})$, sedang $(5-10 \mathrm{~mm})$, dan lemah $(\leq 5 \mathrm{~mm}) .{ }^{47}$

Hasil uji antibakteri menunjukkan bahwa zona hambat yang terbentuk pada kontrol (+) lebih luas dibandingkan zona hambat yang dihasilkan oleh obat kumur ekstrak (konsentrasi 6,25\%, 12,5\%, 25\%, dan 50\%) dan kontrol (-). Hal tersebut disebabkan karena chlorhexidine 0,2\% memiliki aktivitas kerja yang efektif dalam kemampuannya menghambat pertumbuhan bakteri Gram positif. ${ }^{48}$ Pada kontrol (-) tidak terbentuk zona hambat karena akuades tidak memiliki sifat antibakteri yang mampu menghambat pertumbuhan bakteri. ${ }^{49}$

\section{SIMPULAN}

Sediaan obat kumur ekstrak kulit buah naga merah dapat menghambat pertumbuhan bakteri Streptococcus mutans. Obat kumur ekstrak kulit buah naga dengan konsentrasi 50\% memiliki kemampuan menghambat pertumbuhan Streptococcus mutans paling kuat dan menghasilkan zona hambat paling luas dibandingkan obat kumur ekstrak kulit buah naga merah dengan konsentrasi ekstrak 25\%, 12,5\%, dan 6,25\%.

Disarankan untuk melakukan uji biokompatibilitas mengenai sediaan obat kumur ektrak kulit buah naga merah. Selain itu perlu dilakukan uji antibakteri sediaan obat kumur ekstrak kulit buah naga merah terhadap mikroorganisme lain penyebab karies.

\section{Konflik Kepentingan}

Penulis menyatakan tidak terdapat konflik kepentingan dalam studi ini.

\section{DAFTAR PUSTAKA}

1. Badan Penelitian dan Pengembangan Kesehatan. Laporan Nasional RISKESDAS 2018. Jakarta: Kementerian Kesehatan
RI, 2019; p. 204. Available from: https://kesmas.kemkes.go.id/assets/upl oad/dir_519d41d8cd98f00/files/Hasilriskesdas-2018_1274.pdf

2. Pitts NB, Zero DT, Marsh PD, Ekstrand K, Weintraub JA, Ramos-Gomez F, et al . Dental caries. Nat Rev Dis Primers. 2017;3(17030):1-6.

3. Listrianah, Zainur R., Hisata LS. Gambaran karies gigi molar pertama permanen pada siswa- siswi Sekolah Dasar Negeri 13 Palembang tahun 2018. J Kesehat Poltekkes Palembang. 2018;13(2):13941.

4. Sanghi DK, Tiwle R. A comprehensive review on dental carries. J Innov Pharm Biol Sci. 2015;2(4):369-77.

5. Seethalakshmi C, Reddy RCJ, Asifa N, Prabhu $\mathrm{S}$. Correlation of salivary $\mathrm{pH}$, incidence of dental caries and periodontal status in diabetes mellitus patients: a crosssectional study. J Clin Diagnostic Res. 2016;10(3):13.

6. Khamisli Y, Elianora D, Mahata IBE. Hubungan indeks severitas karies dengan $\mathrm{pH}$ saliva pada penyandang tuna grahita di Panti Sosial Bina Grahita (SBG) Harapan Ibu Kalumbuak Kota Padang tahun 2018. J Kedokt Gigi Univ Baiturrahmah. 2018;6(1):72.

7. Ribeiro AA. Biological features of dental caries. JSM Dent. 2016;4(3):1-6.

8. Rosdiana N, Nasution AI. Gambaran daya hambat minyak kelapa murni dan minyak kayu putih dalam menghambat pertumbuhan Streptococcus mutans. J Syiah Kuala Dent Soc. 2016;1(1):43-9.

9. Arif NA, Sukmawaty EKA, Masri M. Sumber daya alternatif antimikroba terhadap bakteri Streptococcus mutans sebagai dental caries (Sebuah Review ). Biol Life J. 2017:44-48.

10. Permatasari D, Budiarti LY, Apriasari ML. Efektivitas antifungi ekstrak metanol batang pisang mauli (Musa acuminata) dan chlorhexidine gluconate $0,2 \%$ terhadap Candida albicans. J Dentino Kedokt Gigi. 2016;I(1):11.

11. Mervrayano J, Bahar E. Perbandingan efektifitas obat kumur yang mengandung chlorhexidine dengan povidone iodine terhadap Streptococcus mutans. J Kesehat Andalas. 2015;4(1):168-71.

12. Kumar SB. Chlorhexidine mouthwash - a review. J Pharm Sci Res. 2017;9(9): 
$1450-2$.

13. Andriani JN. Reduction of salivary Streptococcus mutans colonies in children after rinsing with $2,5 \%$ green tea solution. $\mathrm{J}$ Dent Indones. 2014;21(3):79-84.

14. Shah R, Donde R, Mitra D. Chlorhexidinedifferent forms in dentistry. World $\mathrm{J}$ Adv Sci Res. 2019;2(1):225-31.

15. Laxman V. Chlorhexidine - an insight. Int $\mathbf{J}$ Adv Res. 2016;4(7):2016.

16. Kolliyavar B, Thakur S. Chlorhexidine: the gold standard mouth wash. J Pharmacol Biomed Sci. 2016;6(2):106-9.

17. Prasanna SGV, Lakshmanan R. Characteristics, uses and side effects of chlorhexidine- a review abstract. J Dent Med Sci. 2016;15(6):57-9.

18. Ramli M, Rossani RB, Nadia Y, Darmawan TB. Nanoparticle fabrication of calcium oxide $(\mathrm{CaO})$ mediated by the extract of red dragon fruit peels (Hylocereus polyrhizus) and its application as inorganic - anti-microorganism materials. IOP Conf Series Mater Sci Eng J. 2019:2.

19. Chen J. Phytochemical cocktail - waste utilization of inedible dragon fruit peel. Can Sci Fair J. 2018;1(1):2-8.

20. Ortiz-hernández YD, Carrillo-salazar JA. Pitahaya (Hylocereus spp.): a short review. Comun Sci J. 2012;3(4):220-237.

21. Suhartati R, Roziqin DA. Aktivitas antibakteri ekstrak etanol kulit buah naga merah (Hylocereus polyrhizus) terhadap bakteri Streptococcus pyogenes. J Kesehat Bakti Tunas Husada. 2017;17(2):516-7.

22. Wahdaningsih S, Untari EK, Fauziah Y. Antibakteri fraksi n - heksana kulit Hylocereus polyrhizus terhadap Staphylococcus epidermidis dan Propionibacterium acnes. J Pharm Sci Res. 2014; 1(3):180-93.

23. Balouiri M, Sadiki M, Ibnsouda SK. Methods for in vitro evaluating antimicrobial activity : a review. J Pharm Anal. 2016; 6(2):71-9.

24. Andhika, Sunarintyas S, Widjijono. Pengaruh lama aktivasi panas zeolit terhadap daya antimikroba $\mathrm{Cu}$-Zeolit pada Staphylococcus aureus. Sci J Dent. 2007; 22(4): 128-33.

25. Manihuruk FM, Suryati T, Arief II. Effectiveness of the red dragon fruit (Hylocereus polyrhizus ) peel extract as the colorant, antioxidant, and antimicrobial on beef sausage. J Media
Peternak. 2017;40(1):51.

26. Kumara INC, Agung IG, Pradnyani S, Ayu IG, Novianthi F. Uji efektivitas ekstrak kunyit (Curcuma longa) terhadap daya hambat pertumbuhan bakteri Streptococcus mutans. J Intisari Sains Medis. 2019;10(3):463-4.

27. Artika IM, Bintang M, Rahmawati F. Antibacterial activity and phytochemical analysis of Geranium homeanum Turez Leaves. Curr Biochem J. 2017; 4(3):20.

28. Putri R, Mursiti S, Sumarni W. Aktivitas antibakteri kombinasi temu putih dan temulawak terhadap Streptococcus mutans. J MIPA. 2017;40(1):45.

29. Zain NM, Nazeri MA, Azman NA. Assessment on bioactive compounds and the effect of microwave on pitaya peel. J Teknol. 2019;81(2):12.

30. Ananda A, Putri DKT, Diana S. Daya hambat ekstrak ubi bawang dayak (Eleutherine palmifolia (L.) Merr) terhadap pertumbuhan Streptococcus mutans. J Kedokt Gigi Dentin. 2018;2(1):89.

31. Bontjura S, Waworuntu OA, Siagian KV. Uji efek antibakteri ekstrak daun leilem (Clerodendrum minahassae L.) terhadap bakteri Streptococcus mutans. J Ilm Farm. 2015;4(4):97-9.

32. Hanizar E, Sari DNR. Aktivitas antibakteri Pleurotus ostreatus varietas grey oyster pada Staphylococcus aureus dan Pseudomonas aeruginosa (Antibacterial activity of Pleurotus ostreatus varieties grey oyster on Staphylococcus aureus and Pseudomonas aeruginosa ). E J Pustaka Kesehat. 2018;6(3):390-2.

33. Sari E, Rahmawan D, Sahara M. Daya antibakteri ekstrak kulit buah naga merah (Hylocereus polyrhizus) terhadap bakteri Enterococcus faecalis secara in vitro. J Wiyata. 2021;8(1):99-101.

34. Achmad MH, Ramadhany S, Suryajaya FE. Streptococcus colonial growth of dental plaque inhibition using flavonoid extract of ants nest (Myrmecodia pendans): an in vitro study. Pesqui Bras em Odontopediatria e Clin Intergrada J. 2019;19(4250):1-9.

35. Dewi ZY, Nur A, Hertriani T. Efek antibakteri dan penghambatan biofilm ekstrak sereh (Cymbopogon nardus L.) terhadap bakteri Streptococcus mutans. Maj Kedokt Gigi Indones. 2015;1(2):138-40. 
36. Made N, Rakasari G, Duniaji AS, Nocianitri KA. Kandungan senyawa flavonoid dan antosianin ekstrak kayu secang (Caesalpinia sappan L.) serta aktivitas antibakteri terhadap vibrio cholerae. J Ilmu dan Teknol Pangan. 2019;8(2): 222-3.

37. Setiani D. Antibacterial activity testing of red dragon fruit peel on Pseudomonas Sp. Str J Ilm Kesehat. 2020;9(1):306.

38. Sartika D, Sutikno, Yuliana N, Maghfiroh SR. Identifikasi senyawa antimikroba alami pangan pada ekstrak kulit buah naga merah dengan menggunakan GC-MS. J Teknol dan Ind Has Pertan. 2019;24(2): 70-5.

39. Faridah A, Syukri D, Holinesti R. Aktivitas antibakteri ekstrak etanol 60\% dan ekstrak air kulit buah naga merah terhadap bakteri Staphylococcus aureus dan Escherichia coli. J Reka Pangan. 2015; 9(1):16-7.

40. Jati NK, Prasetya AT, Mursiti S. Isolasi, identifikasi, dan uji aktivitas senyawa alkaloid pada daun pepaya. J MIPA. 2019;42(1):5-6.

41. Levinson W, Chin-hong P, Joyce EA, Nussbaum J, Schwartz B. Review of Medical Microbiology and Immunology A Guide to Clinical Infectious Diseases (15th ed). United States of America: McGraw-Hill Book Companies Inc, 2018.

42. Rahman FA, Haniastuti T, Utami TW. Skrining fitokimia dan aktivitas antibakteri ekstrak etanol daun sirsak (Annona muricata L.) pada Streptococcus mutans ATCC 35668. Maj Kedokt Gigi Indones. 2017;3(1):5.

43. Hamidah MN, Rianingsih L, Romadhon. Aktivitas antibakteri isolat bakteri asam laktat dari peda dengan jenis ikan berbeda terhadap E.coli dan S.aureus. J Ilmu dan Teknol Perikan. 2019;1(2):179.

44. Ariyani H, Nazemi M, Hmidah, Kurniati M. Uji efektivitas antibakteri ekstrak kulit limau kuit (Cytrus hystrix D) terhadap beberapa bakteri. J Curr Pharm Sci. 2018;2(1):138.

45. Agung A, Astridwiyanti B, Mahendra AN, Wayan N, Dewi S. Uji efektivitas ekstrak etanol kulit buah naga merah (Hylocereus polyrhizus) terhadap Staphylococcus aureus ATCC 25923 secara in vitro. J Intisari Sains Medis. 2019;10(3):484-48॥15.

46. Surjowardojo P, Susilorini TE, Sirait GRB. Daya hambat dekok kulit apel manalagi (Malus sylvestrs Mill) terhadap pertumbuhan Staphylococcus aureus dan Pseudomona sp. penyebab mastitis pada sapi perah. J Ternak Trop. 2015;16(2):44.

47. Rastina, Sudarwanto M, Wientarsih I. Aktivitas antibakteri ekstrak etanol daun kari (Murraya koenigii) terhadap Staphylococcus aureus, Escherichia coli, dan Pseudomonas sp. J Kedokt Hewan. 2015;9(2):187.

48. Zubaidah N, Juniarti DE, Basalamah F. Perbedaan daya antibakteri ekstrak temulawak (Differences of antibacterial agent temulawak extract (Curcuma xanthorrhiza Roxb.) 3,125\% and chlorhexidine $0,2 \%$ to inhibit Lactobacillus acidophilus). Conserv Dent J. 2018;8(1):7-8.

49. Wahyuni, Karim SF. Uji aktivitas antibakteri ekstrak etanol daun kacapiring (Gardenia jasminoides Ellis) terhadap bakteri Streptococcus mutans. J Sains dan Kesehat. 2020;2(4):402-3. 